high-dose megavoltage $x$-ray technique. The clinical nature of the damage has been assessed and an attempt made to establish the site of damage.

Of the patients receiving 6,300 rads peak dose in 25 to 26 days neurological symptoms were complained of by $73 \%$, and of the group receiving 5,775 rads peak dose by $15 \%$. In the higher-dose group the majority of patients with symptoms had abnormal neurological signs.

Pathological data in two cases are given and mention is made of factors other than radiation which may have contributed to the nerve damage noted. It is concluded that high-dose, smallfield megavoltage irradiation following radical surgery leads to delayed damage to the brachial plexus, the incidence being related to the level of dosage. Our past experience with other techniques has been analysed for purposes of comparison.
We wish to thank Dr. P. Bladin, of St. Vincent's Hospital, Melbourne, for his co-operation in the electromyographic studies mentioned, and Dr. W. P. Holman, Medical Director, for his constant interest in the clarification of this problem.

\section{REFERENCES}

Ackland, T. H., Holman, W. P., and Stoll, B. A. (1960). Med. F. Aust.,

1, 793. C., Harrison, F., and Bonte, F. J. (1961). Radiology, 77, 264. Clemedson, C. J., and Nelson, A. (1960). In Mechanisms in Radiobiology, vol.' 2, p. 144, edited by M. Errera and A. Forssberg. Academic Press, New York.

Innes, J. R., and Carsten, A. (1961). Brookhaven Symp. Biol., 14, 200.

Janzen, A. H., and Warren, S. (1942). Radiology, 38, 333.

Linder, R. (1959). Fortschr. Röntgenstr., 90, 617. Quoted by R. Bergström, Acta radiol. (Stockh.), 1962, 58, 301.

Thompson, W. A. L., and Kopell, H. P. (1959). New Engl. F. Med., 260, 1261 .

Treves, N. (1957). Cancer (Pkilad.), 10, 444.

\title{
Significance of the Complement-fixation Test in Diagnosis of Amoebiasis in an Endemic Area
}

\author{
R. M. KASLIWAL,* M.D., F.R.C.P., F.N.I., F.A.M.S. ; MICHAEL KENNEY, † M.D.; M. L. GUPTA,* M.D. \\ J. P. SETHI,* M.D. ; JOSEPH S. TATZ ; CLARISE H. ILLES $\dagger$
}

Brit. med. F., 1966, 1, 837-838

Amoebiasis is a disease of world-wide distribution but is particularly prevalent in tropical countries such as India. The condition may be manifested by intestinal or extra-intestinal symptoms. In intestinal amoebiasis the basis on which diagnosis is made is the presence of Entamoeba histolytica in the stools. In extra-intestinal amoebiasis difficulties are encountered in making a definite diagnosis, since the stools show $E$. histolytica in only a small percentage of cases. The decision in such cases is based on the clinical picture, haematological examination, and radiological signs. The need for a reliable laboratory test has long been felt.

Craig (1927, 1929, 1930, 1933, 1937) and Craig and Scott (1935) recognized the value of the complement-fixation test in the diagnosis of amoebiasis. Since then a number of reports have been published (Meleney and Frye, 1937 ; Rees et al., 1942 ; Ghosh et al., 1948 ; Terry and Bozicevich, 1948 ; Hussey and Brown, 1950 ; Dolkart et al., 1951; McDearman and Dunham, 1952). There has been wide variation in the observations made by various workers, mainly because of the different types of antigen used and the techniques employed. Furthermore, the reliability of a complement-fixation test for amoebiasis in hyperendemic areas, where it is needed most, has often been questioned because of strong anamnestic reactions resulting from repeated infection with $E$. histolytica.

\section{Present Investigations}

This study was undertaken to evaluate the significance of the complement-fixation test in both intestinal and hepatic amoebiasis in India by means of an antigen which had proved to be a reliable diagnostic tool in New York.

Material and Methods.-Complement-fixation tests for amoebiasis were carried out on cases of chronic intestinal

* Department of Medicine, S.M.S. Medical College, Jaipur, India. † Laboratory Service, Veterans Administration Hospital, New York. ¥ Area Reference Laboratory, Veterans Administration Hospital, Bronx, N.Y. amoebiasis, hepatic amoebiasis, and controls, including normal individuals and patients with conditions other than amoebiasis.

The diagnosis of amoebic hepatitis was made on the finding of an enlarged tender liver, together with a history of blood and mucus in the stools, and either positive stool culture for $E$. histolytica or sigmoidoscopic evidence of typical amoebic ulcers.

All the cases were evaluated by a detailed clinical history, a complete physical examination, laboratory measures, including liver-function tests, and repeated stool examination. The complement-fixation test was performed with the Micro-Kolmer technique as described by Kenney (1952). The antigen was prepared by the New York Group, using the method described by Kenney (1952), and shipped to India in a lyophilized state.

\section{Results}

Among 45 cases of intestinal amoebiasis the complementfixation test was positive in only $7(15.5 \%)$ cases (Table I). All of them had $E$. histolytica cysts in the stools. One patient harboured $E$. histolytica trophozoites in addition, and a

TABLE I.-Results of Complement-fixation Tests

\begin{tabular}{|c|c|c|c|c|}
\hline \multirow{2}{*}{\multicolumn{2}{|c|}{ Clinical Diagnosis }} & \multirow{2}{*}{$\begin{array}{l}\text { No. of } \\
\text { Cases }\end{array}$} & \multicolumn{2}{|c|}{ Positive C.F.T. } \\
\hline & & & No. & $\%$ \\
\hline $\begin{array}{l}\text { Intestinal amoebiasis } \\
\text { Amoebic hepatitis } \\
\text { Amoebic abscess of liver } \\
\text { Normal controls (no eviden }\end{array}$ & $\begin{array}{ccc}\because & \cdots & \cdots \\
\ddot{c e} & \because & \because \\
\text { ce of any disease) }\end{array}$ & $\begin{array}{r}45 \\
12 \\
5 \\
10\end{array}$ & $\begin{array}{r}7 \\
10 \\
5 \\
0\end{array}$ & $\begin{array}{r}15 \cdot 5 \\
83 \cdot 3 \\
100.0 \\
0\end{array}$ \\
\hline
\end{tabular}

complement-fixation test was positive. All five cases of amoebic abscess of the liver had positive complement-fixation tests. In $10(83 \%)$ of the 12 cases originally regarded as amoebic hepatitis the complement-fixation test was positive. None of the 10 normal controls without evidence of any disease had a positive complement-fixation test. 
In all 15 cases of hepatomegaly due to various diseasesanaemia (4), cirrhosis of liver (4), infectious hepatitis (2), congestive heart failure (1), chronic pyelonephritis (1), chronic cholecystitis with secondary syphilis (1), enteric fever (1), and tabes mesenterica (1)-but showing no evidence of amoebiasis the complement-fixation test was negative.

Table II shows that four out of seven positive complementfixation tests in cases of intestinal amoebiasis gave positive results in $1: 2$ dilution of the serum.

\begin{tabular}{|c|c|c|c|c|c|c|c|c|}
\hline \multirow{2}{*}{ Clinical Diagnosis } & \multirow{2}{*}{$\begin{array}{l}\text { No. of } \\
\text { Cases }\end{array}$} & \multirow{2}{*}{$\begin{array}{l}\text { Pos. } \\
\text { C.F.T. }\end{array}$} & \multirow{2}{*}{$\begin{array}{l}4+\text { in } \\
\text { Serum } \\
\text { Undil. }\end{array}$} & \multicolumn{5}{|c|}{$4+$ in Serum Dilution } \\
\hline & & & & $1: 2$ & $1: 4$ & $1: 8$ & $1: 16$ & $1: 32$ \\
\hline \multirow{3}{*}{$\begin{array}{l}\text { Intestinal amoe- } \\
\text { biasis } \because \\
\text { Amoebic hepatitis } \\
\text { Amoebic abscess of } \\
\text { liver } \ldots\end{array}$} & 45 & 7 & - & 4 & 2 & - & 1 & - \\
\hline & 12 & 10 & 2 & - & 3 & 1 & 3 & 1 \\
\hline & 5 & 5 & - & - & - & - & 3 & 2 \\
\hline
\end{tabular}

\section{Discussion}

Various results of complement-fixation tests in cases of intestinal amoebiasis have been reported in the literature. Hussey and Brown (1950), McDearman and Dunham (1952), and Spicknall et al. (1957) recorded positive complementfixation tests in $2.4 \%, 15 \%$, and $17.5 \%$, respectively, of their cases of intestinal amoebiasis. In the present study the complement-fixation test was positive in $15.5 \%$ of the cases of intestinal amoebiasis with $E$. histolytica cysts present in the stools. These figures. are in fair agreement with the reports of McDearman and Dunham (1952) and Spicknall et al. (1957). Kenney et al. (1955) obtained positive complement-fixation tests, ranging from $27 \%$ to $91 \%$ in various groups of patients, related to the presence of $E$. histolytica trophozoites or cysts in the stools, the duration of amoebiasis, and in symptomatic cases or asymptomatic carriers. The lowest percentage was observed in asymptomatic carriers of $E$. histolytica cysts and the highest among symptomatic patients with amoebiasis of long duration, harbouring $E$. histolytica trophozoites.

In amoebic involvement of the liver the incidence of positive complement-fixation tests is said to be significantly high. Terry and Bozicevich (1948) reported positive tests in $86.7 \%$, Hussey and Brown (1950) in $83.4 \%$, McDearman and Dunham (1952) in $86 \%$, Spicknall et al. (1957) in $88 \%$, and Kenney et al. (1955) in $100 \%$ of cases with hepatic amoebiasis.

In the present study complement-fixation tests in a group reported to have hepatic amoebiasis were found to be positive in 10 out of 12 cases $(83 \%)$. However, the two cases in which the complement-fixation test was negative did not have a definite past history of intestinal amoebiasis, and there is a strong possibility that in these two cases hepatitis was due to other than amoebic causes, and the tests should not therefore be definitely regarded as false-negatives. In amoebic abscess of the liver the test was positive in all the five cases. Thus in hepatic amoebiasis as a whole complement-fixation tests were found to be positive in at least $88 \%$ of the cases, which is in fair agreement with other published reports.

Study of complement-fixation tests in normal controls and in patients with hepatomegaly but without evidence of amoebiasis revealed negative reactions in all the cases. This would indicate the value of the complement-fixation test in differentiating between amoebic involvement of the liver and hepatomegaly due to other causes.

The liver was found to be enlarged, with little or no tenderness, in 37 out of 45 cases of intestinal amoebiasis without any constitutional or radiological signs. However, the incidence of positive complement-fixation tests in such cases was markedly low $(13.5 \%)$. It is possible that in such cases there is no definite amoebic invasion of the liver, but its enlargement may be due to the associated toxaemia and anaemia so commonly encountered in cases of intestinal amoebiasis described as "pre-hepatitis" by Kasliwal and Bhatia (1956).

McDearman and Dunham (1952) attempted to correlate the antibody titres with the duration and severity of extra-intestinal amoebiasis, and though they found no correlation of the titres with the duration of illness it was observed that the antibody titre was affected by the severity of the disease. A correlation between the antibody titre and the amoebic manifestation in the present study revealed that in cases of intestinal amoebiasis with positive complement-fixation tests titres as low as $1: 2$ dilution of serum were observed in $57 \%$. On the contrary, in amoebic hepatitis $80 \%$ of the positive complement-fixation tests had titres from $1: 4$ to $1: 32$ dilutions of serum-that is, titres that were considered to be high. Even higher titres, such as $1: 16$ to $1: 32$ dilution of serum, were observed in $100 \%$ of cases with amoebic abscesses of the liver. It appears, therefore, that there is a direct correlation between the antibody titre and the extent of invasion of the tissues by $E$. histolytica. Thus in cases of hepatic amoebiasis the complement-fixing antibody titres were found to be high in $87 \%$, while in intestinal amoebiasis they were high in only $43 \%$.

\section{Summary}

A study of the complement-fixation test for amoebiasis performed in an endemic area by means of the Micro-Kolmer technique in 87 cases is presented. There were 45 cases of intestinal amoebiasis, 12 cases of amoebic hepatitis, and five cases of amoebic abscess of the liver. Ten normal individuals and 15 patients with hepatomegaly but no evidence of amoebiasis served as controls. In intestinal amoebiasis complement-fixation tests were found to be positive in $15.5 \%$ of the cases. In amoebic hepatitis the test was positive in $83 \%$ of the cases, and in amoebic abscess of the liver in $100 \%$. Controls gave negative results in all cases. A correlation of antibody titre with the type of amoebic involvement revealed that the titres were low in intestinal amoebiasis and high in amoebic hepatitis and amoebic abscess of the liver. The results show that the complement-fixation test is highly significant in the diagnosis of extra-intestinal amoebiasis and in differentiating it from other causes of hepatomegaly. On the contrary, the absence of falsepositive tests in the studied group suggests that when a specific purified amoebic antigen is used anamnestic reactions do not interfere with the reliability of the amoebic complement-fixation test in a hyperendemic area, where it is needed most.

\section{REFERENCES}

Craig, C. F. (1927). Amer. f. trop. Med., 7, 225.

(1928). Ibid., 8, 29.

(1929). Ibid., 9, 277

(1930). 7. Amer. med. Ass., 95, 10

(1933). 7. Lab. clin. Med., 18, 873

(1937). Amer. f. publ. Hlth, 27, 689.

and Scott, L. C. (1935). Proc. Soc. exp. Biol. (N.Y.), 32, 958. Dolkart, R. E., Halpern, B., and Cullen, J. (1951). 7. Lab. clin. Med.,
38, 804.

Ghosh, N. N., Ghosh, H., and Ray, J. C. (1948). Ann. Biochem., 8, 3.

Hussey, K. L., and Brown, H. W. (1950). Amer. F. trop. Med., 30, 147

Kasliwal, R. M., and Bhatia, M. L. (1956). F. Indian med. Ass., 27, 127.

Kenney, M. (1952). Amer. F. trop. Med. Hyg., 1, 717.

Wolf, J., and Tatz, J. S. (1955). Amer. Practit., 6, 1201.

McDearman, S. C., and Dunham, W. B. (1952). Amer. F. trop. Med. Hyg., 1, 182 .

Meleney, H. E., and Frye, W. W. (1937). Amer. f. publ. Hlth, 27, 505. Rees, C. W., Bozicevich, J., Reardon, L. V., and Jones, F. (1942). Amer.
f. trop. Med., 22, 581. Spicknall, C. G., Bozicevich, J., Black, R. L., and Terry, L. L. (1957).
Gastroenterology, 32, 1131

Terry, L. L., and Bozicevich, J. (1948). Sth. med. F. (Bgham, Ala.), 41, 